\title{
Purification to Apparent Homogeneity and Biochemical Characterization of Human Pluripotent Hematopoietic Colony- Stimulating Factor *
}

\author{
K. Welte, E. Platzer, J. L. Gabrilove, L. Lu, E. Levi, A. Polivka, R. Mertelsmann
} and M.A.S. Moore

\section{A. Introduction}

Colony-stimulating factors (CSFs) are a family of hematopoietic growth factors required for the proliferation and differentiation of hematopoietic progenitor cells [1, 2]. In the human system, purification to homogeneity and biochemical characterization has only been reported for macrophage-active CSF (CSF-1) [3]. However, there are many reports about highly purified human granulocyte-macrophage CSFs (e.g. [4-7]), but not about pluripotent human CSF.

Assays are available to detect human clonogenic precursors that give rise to cells of the erythroid, granulocytic, megakaryocytic, macrophage, colony-forming unit granulocytes, erythrocytes, macrophages, and megakaryocytes, CFU-GEMM, and possibly lymphoid lineages [8-10]. CSFs with activities on these pluripotential progenitor cells (pluripotent CSF) are produced by mitogen- or antigen-activated T-lymphocytes [11] and by human tumorcell lines [12] or HTLV-transformed lymphoid cells [13].

We report in this paper the purification to homogeneity and biochemical charac-

* Laboratory of Developmental Hematopoiesis and Laboratory of Molecular Hematology, Memorial Sloan-Kettering Cancer Center, New York, NY 10021

Supported by NIH grants CA 20194, CA 31780 , CA 32516, CA 33873, and CA 34995, American Cancer Society grants $\mathrm{CH} 251$ and $\mathrm{CH}-3 \mathrm{GH}$, NCI grant K08-CA00966-01, and the Gar Reichman Foundation terization of a human pluripotent CSF, produced and released by the human bladder carcinoma-cell line 5637.

\section{B. Assay Systems}

Granulocyte-macrophage-CSF (GM-CSF), granulocyte-macrophage-erythrocyte-megakaryocyte-CSF (GEMM-CSF), and early erythroid burst-forming unit (BFU-E) activities were tested on low-density, T-celldepleted, nonadherent human bone marrow cells as described [14-15] and detailed in another paper by Platzer et al. in this volume. For assay of differentiation induction, the method of Metcalf [16] was used, whereby pluripotent CSF was added to cultures of the murine myelomonocytic WEHI-3B $(\mathrm{D}+)$ or the human promyelocytic HL-60 leukemic cells and scored for differentiation on day 7 and 14 respectively.

As shown in the Results, a single protein stimulates colony formation by CFUGEMM, BFU-E, and CFU-GM progenitor cells. We termed this protein "pluripotent CSF" or "pluripoietin". Due to the low numbers of mixed colonies per dish attainable in this assay system, titration of test samples for determination of pluripotent CSF activity presented difficulties in quantitation. Therefore, we used the GM-CSF assay as described $[14,15]$ to measure the GM-CSF aspect of the pluripotent CSF in the samples that supported growth of CFUGEMM and BFU-E for calculating the specific activities throughout the purification procedure. 
Table 1. Purification of human pluripotent CSF

\begin{tabular}{|c|c|c|c|c|c|}
\hline & $\begin{array}{l}\text { Total } \\
\text { activity } \\
\text { (units) }^{\mathrm{a}}\end{array}$ & $\begin{array}{l}\text { Total } \\
\text { protein } \\
(\mathrm{mg})\end{array}$ & $\begin{array}{l}\text { Specific } \\
\text { activity } \\
\text { (units/mg) }\end{array}$ & $\begin{array}{l}\text { Purification } \\
\text { (-fold) }\end{array}$ & $\begin{array}{l}\text { Yield } \\
(\%)\end{array}$ \\
\hline Conditioned media $(20 \mathrm{~L})$ & $\times 10^{6}$ & 2000 & 6000 & - & 100 \\
\hline $\begin{array}{l}\text { DE } 52 \text { ion exchange chroma- } \\
\text { tography }\end{array}$ & $\times 10^{6}$ & 300 & 16700 & $1^{\mathrm{b}}$ & 42 \\
\hline AcA 54 gel filtration & $3.1 \times 10^{6}$ & 13.2 & 235000 & $14^{\mathrm{b}}$ & 26 \\
\hline HPLC reverse phase & $0.74 \times 10^{6}$ & 0.005 & $1.5 \times 10^{8}$ & $9000^{\mathrm{b}}$ & 6.2 \\
\hline
\end{tabular}

a Units of activity in the GM-CSF assay in agar, as tested on low-density normal human bone marrow cells

b Estimate of -fold purification based on starting activity from one selected peak of DE 52

\section{Purification of Pluripotent CSF}

The human bladder carcinoma-cell line 5637 has been reported to produce constitutively a GM-CSF [17] and GEMMCSF [12]. The cells were cultured in RPMI 1640 supplemented with glutamine $(2 \mathrm{mM})$, antibiotics, and $10 \%$ fetal calf serum (FCS). For production of pluripotent CSF used for purification cells were kept for 48-72 $\mathrm{h}$ in medium containing low serum $(0.2 \% \mathrm{FCS})$. The conditioned medium from low-serum-containing cultures was harvested and used for purification. The first three steps of purification involved ammonium sulfate precipitation (80\% saturation), anion-exchange chromatography [diethylaminoethanol (DEAE)-cellulose, DE 52, Whatman, Clifton, NJ], and gel filtration (AcA 54 Ultrogel, LKB Products, Inc., Rockland, MD) (Table 1). These steps were used because they were highly effective for other cytokines, notably Interleukin 2 [18] and B-cell-differentiating factor [19] and have been described in detail elsewhere [18]. Pluripotent CSF eluted from the DE 52 cellulose column between 0.075 and $0.1 M \mathrm{NaCl}$ in $0.05 \mathrm{M}$ Tris $/ \mathrm{HCl}$, $\mathrm{pH} 7.8$, and from the AcA 54 column with a single peak at around 32000 molecular weight. The final step involved chromatography on a reverse-phase high-performance liquid chromatography (HPLC) column (uBondapak C 18, Waters) and a Waters HPLC system using 1-propanol as organic solvent $(20 \%-50 \%$ 1-propanol gradient in $2 \mathrm{~h}$ ) and a buffer system con- taining $0.9 \mathrm{M}$ acetic acid and $0.2 \mathrm{M}$ pyridine, $\mathrm{pH}$ 4.0. Pluripotent CSF activity eluted as a single peak at $42 \%$ 1-propanol. The purification schedule with degree of purification of pluripotent CSF as measured by GM-CSF activity, protein content, specific activity, and yield is detailed in Table 1 . We obtained a specific activity of $1.5 \times 10^{8} \mathrm{U} /$ mg protein.

\section{Biochemical Characterization of Pluripotent CSF}

The final preparation obtained after HPLC was analyzed on a $15 \%$ sodium dodecyl sulfate polyacrylamide gel electrophoresis (SDS-PAGE) gel [20] followed by the sensitive silver staining technique (Biorad Lab., Rockville Centre, NY; Fig. 1). Only one protein band with a molecular weight of 18000 was seen under reducing (5\% 2-mercaptoethanol; Fig. 1) and nonreducing (not shown) conditions. After electrophoresis under nonreducing conditions, a parallel gel was sliced into $2-\mathrm{mm}$ sections and proteins eluted from each slice into phosphate buffer. Pluripotent CSF was found to be localized in the slice number corresponding to 18000 molecular weight (Fig. 1). Reelectrophoresis of the protein in the active slice-fraction with SDS-PAGE under reducing conditions revealed again a protein band of 18000 molecular weight (not shown).

The purified pluripotent CSF was also subjected to isoelectrofocusing analysis in 


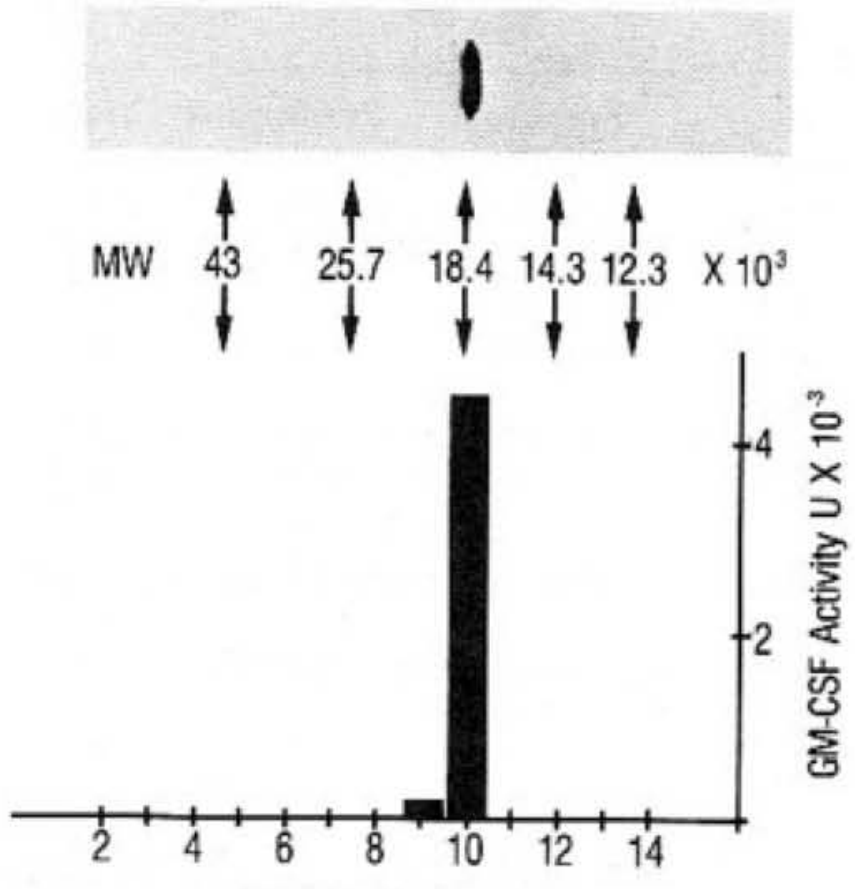

Gel Slice Number

Fig. 1. $S D S-P A G E$. The pluripotent CSF eluted from the HPLC column (peak fraction) was lyophilized and treated with $1 \%$ SDS in $0.065 \mathrm{M}$ Tris/ $\mathrm{HCl}, \mathrm{pH} 6.8$, and $20 \%$ glycerol, under reducing conditions (5\% 2-mercaptoethanol) for $1 \mathrm{~h}$ at $37^{\circ} \mathrm{C}$ and then applied to a $15 \%$ polyacrylamide gel [20]. After electrophoresis, the proteins were visualized by the silver staining technique (upper panel). Treatment of pluripotent CSF under nonreducing conditions and subsequent electrophoresis gave the same results. For elution of biological activity pluripotent CSF was treated as above (nonreducing conditions) and after electrophoresis under the same conditions the gel was sliced into 2-mm sections and proteins from each slice were eluted into phosphate buffer ( $20 \mathrm{mM}, \mathrm{pH} 7.2)$. After $18 \mathrm{~h}$ eluted proteins were assayed for pluripotent activity (lower panel; GM-CSF activity, black columns). The following marker proteins (arrows) were used: ovalbumin (molecular weight, 43000 ), chymotrypsinogen (molecular weight, 25700 ), lactoglobulin (molecular weight, 18400 ), lysozyme (molecular weight, 14300 ), and cytochrome C (molecular weight, 12300 )

Table 2. Biochemical characteristics of human pluripotent CSF

\begin{tabular}{lc}
$\begin{array}{l}\text { Molecular weight } \\
\text { (AcA 54 gel filtration) }\end{array}$ & 32000 \\
Molecular weight (SDS-Page) & 18000 \\
Isoelectric point & 5.5 \\
pH stability & $2-9$ \\
Binding to concanavalin A-agarose & No \\
\hline
\end{tabular}

an IEF column (LKB 8100) [18] using ampholines with a $\mathrm{pH}$ range of $3.5-10$. Pluripotent CSF was localized in one fraction with a $\mathrm{pH}$ of 5.5 (Table 2).

\section{E. Biological Activity of Pluripotent CSF}

Fifty units of GM-CSF activity of pluripotent CSF $\left(1.8 \times 10^{-11} M\right)$ supported the half-maximal cloning of CFU-GM, while $500 \mathrm{U} / \mathrm{ml}$ was needed to support the cloning of human CFU-GEMM and BFU-E. In addition pluripotent CSF at a concentration of between 500 and $1000 \mathrm{U} / \mathrm{ml}$ was capable of inducing differentiation of the leukemic cell lines HL-60 and WEHI$3 \mathrm{~B}(\mathrm{D}+)$. A detailed biological characterization of pluripotent CSF is described in the paper by Platzer et al. in this volume.

\section{F. Discussion}

The protein described in this paper is capable of stimulating the in vitro growth of human mixed colony progenitor cells (CFU-GEMM), early erythroid progenitor cells (BFU-E), and granulocyte-macrophage progenitors (CFU-GM) and in addition induces differentiation of the murine myelomonocytic (WEHI-3B(D+)) and the human promyelocytic (HL-60) leukemic cell lines. It has a molecular weight of 18000 and an isoelectric point of 5.5. The specific activity is $1.5 \times 10^{8} \mathrm{U} / \mathrm{mg}$ protein. The purified protein, shown in Fig. 1, and the pluripotent CSF activity are identical because: (1) protein and activity eluted in the same fraction from the HPLC; (2) we were not able to separate biological activity and the 18000 molecular weight protein by using additional HPLC columns (Diphenyl, C4, Hydroxylapatite) and buffer systems; (3) identical localization of protein and activity in SDS-PAGE (Fig. 1); (4) high specific activity $\left(1.5 \times 10^{8} \mathrm{U} / \mathrm{mg}\right.$ protein; $1 \mathrm{U}=3.7 \times 10^{-13} \mathrm{M}$ ), which is comparable to pure murine CSF [21] and human CSF-1 [3]. Therefore, it is very unlikely that pluripotent CSF activity is not associated with the 18000 molecular weight protein. 
The availability of purified human pluripotent CSF has important and farreaching implications for the analysis of human hematopoiesis and possibly for the understanding and management of clinical diseases involving hematopoietic derangement or failure.

Acknowledgment. We would like to thank Ms. Maureen Sullivan and Mr. John Foster for excellent technical assistance.

\section{References}

1. Burgess AW, Metcalf D (1980) The nature and action of granulocyte-macrophage colony-stimulating factors. Blood 56:947 $-958$

2. Nicola NA, Vadas M (1984) Hematopoietic colony-stimulating factors. Immunol Today 5:76-81

3. Das SK, Stanley ER (1982) Structure-function studies of a colony stimulating factor (CSF-1). J Biol Chem 257:13 679-13 684

4. Wu MC, Yunis AA (1980) Common pattern of two distinct types of colony-stimulating factor in human tissues and cultured cells. $J$ Clin Invest 65:772-775

5. Lusis AJ, Quon DH, Golde DW (1981) Purification and characterization of a human T-lymphocyte-derived granulocyte-macrophage colony-stimulating factor. Blood 57:13-21

6. Abboud $\mathrm{CN}$, Brennan JK, Barlow $\mathrm{GH}$, Lichtman MA (1981) Hydrophobic adsorption chromatography of colony-stimulating activities and erythroid-enhancing activity from the human monocyte-like cell line CGT. Blood 58:1148-1154

7. Motoyoshi K, Suda T, Kusumoto K, Takaku F, Miura Y (1982) Granulocyte-macrophage colony-stimulating and binding activities of purified human urinary colony-stimulating factor to murine and human bone marrow cells. Blood 60: 1378-1391

8. Fauser AA, Messner HA (1978) Granulocyte-erythropoietic colonies in human bone marrow, peripheral blood and cord blood. Blood 52: 1243-1248

9. Fauser AA, Messner HA (1979) Identification of megakaryocytes, macrophages and eosinophils in colonies of human bone marrow containing neutrophilic granulocytes and erythroblasts. Blood 53: 1023-1027
10. Messner HA, Izaguirre CA, Jamal N (1981) Identification of $\mathrm{T}$ lymphocytes in human mixed hematopoietic colonies. Blood 58: 402-405

11. Ruppert S, Lohr GW, Fauser AA (1983) Characterization of stimulatory activity for human pluripotent stem cells (CFUGEMM). Exp Hematol 11:154-161

12. Myers CD, Katz FE, Joshi G, Millar JL (1984) A cell line secreting stimulating factors for CFU-GEMM culture. Blood 64: 152-155

13. Salahuddin SZ, Markham PD, Lindner SG, Gootenberg J, Popovic M, Hemmi H, Sarin PS, Gallo RC (1984) Lymphokine production by cultured human $T$ cells transformed by human $T$ cell leukemia-lymphoma virus-I. Science 223:703-707

14. Broxmeyer HE, Moore MAS, Ralph P (1977) Cell-free granulocyte colony inhibitory activity derived from human polymorphonuclear neutrophils. Exp Hematol 5: 87-102

15. Li L, Broxmeyer HE, Meyers PA, Moore MAS, Tzvi Thaler H (1983) Association of cell cycle expression of Ia-like antigenic determinants on normal human multipotential (CFU-GEMM) and erythroid (BFU-E) progenitor cells with regulation in vitro by acidic isoferritins. Blood 61:250-256

16. Metcalf D (1980) Clonal extinction of myelomonocytic leukemic cells by serum from mice injected with endotoxin. Int $J$ Cancer 25:225-233

17. Svet-Modalsky GJ, Zinzer SN, Svet-Modalsky IA, Mann PE, Holland JF, Fogh J, Arlin Z, Clarkson BD (1980) CSF-producing human tumor cell lines. Lack of CSF activity of human stromal bone marrow fibroblasts. Exp Hematol 8 [Suppl] 7:76 (abstract)

18. Welte $\mathrm{K}$, Wang CY, Mertelsmann $\mathrm{R}$, Venuta S, Feldman S, Moore MAS (1982) Purification of human interleukin 2 to apparent homogeneity and its molecular heterogeneity. J Exp Med 165:454-464

19. Ralph P, Welte K, Levi E, Nakoinz I, Litkovsky PB, Mertelsmann R, Moore MAS (1984) Human B cell-inducing factor(s) for production of IgM, IgG and IgA: independence from IL2. J Immunol 132:1858 $-1862$

20. Laemmli UK (1970) Cleavage of structural proteins during the assembly of the head of bacteriophage T4. Nature 227:680-685

21. Ihle $J \mathbf{N}$, Keller J, Henderson L, Klein F, Palaszynski E (1982) Procedures for the purification of interleukin 3 to homogeneity. J Immunol 129:2431-2436 